\title{
TEKNIK PEMBELAJARAN DARING TERHADAP PEMBELAJARAN CERPEN DI SMPN 7 KOTA TANGERANG
}

\author{
Sumiyani \\ Universitas Muhammadiyah Tangerang \\ Sumiyani.kinanti@gmail.com
}

\begin{abstract}
ABSTRAK
Tujuan penelitian ini adalah untuk mendeskripsikan Teknik Pembelajaran Daring Terhadap Pembelajaran puisi di kelas 9 SMPN.7 Kota Tangerang. Siswa diharapkan memiliki kemampuan menggunakan teknologi untuk Pembelajaran Jarak Jauh. PJJ mengharuskan siswa menguasai, menggunakan dan memanfaatkan teknologi. Pemanfaatan teknologi dalam pembelajaran cerpen ini banyak digunakan ketika masa pandemic. Pendekatan penelitian yang digunakan adalah pendekatan kualitatif dengan jenis metode penelitian deskriptif kualitatif metode penelitian kualitatif adalah metode penelitian yang berlandaskan pada Filsafat postpositivme, digunakan untuk meneliti kondisi objek yang ilmiah, dan peneliti sebagai instrument metode yang digunakan dalam penelitian ini adalah metode kualitatif deskriptif. Instrumen yang digunakan berbentuk google form dan Whatsaap. Selain google form dan Whatsaap, peneliti juga menggunakan instrumen daftar pertanyaan wawancara, observasi dan dokumentasi. Berdasarkan 20 instrumen telah dianalisis, dapat disimpulkan bahwa rasa suka terhadap pembelajaran cerpen ada : $35 \%$ siswa sangat menyukai pelajaran cerpen, $56 \%$ siswa menyukai pelajaran cerpen, 9\% merasa biasa saja dengan pelajaran cerpen. dan rasa suka terhadap pembelajaran daring melalui Google Form Ada 52\% siswa sangat menyukai pembelajaran daring, dan $48 \%$ siswa menyukai
\end{abstract}

Kata kunci: Pembelajaran Daring, Pembelajaran Cerpen

\section{A. PENDAHULUAN}

Pendidikan adalah proses mengembangkan kemampuan diri sendiri secara sistematis dengan menggunakan metode-metode ilmiah tertentu .perbuatan mendidik ini adalah proses bantuan yang diberikan oleh orang dewasa kepada anak yang belum dewasa untuk mencapai kedewasaannya dalam rangka mempersiapkan dirinya untuk kehidupan yang bermakna. Pendidikan merupakan suatu kegiatan yang akan merubah pola pikir manusia dari yang tidak tahu menjadi tahu dan dari yang tidak bisa menjadi bisa. Pendidikan mempunyai peran yang sangat penting, karena didalam pendidikan seseorang akan belajar untuk memperoleh pengetahuan, pemahaman, keterampilan, dan sikap seseorang menuju kedewasaan yang akan menghasilkan perubahan positif. Pendidikan adalah usaha sadar dan terencana untuk mewujudkan suasana belajar dan proses pembelajaran agar peserta didik secara aktif mengembangkan potensi dirinya untuk memiliki kekuatan spiritual, keagamaan, pengendaliaan diri, kecerdasaan, akhlak 
mulia, serta keterampilan yang diperlukan dirinya, masyarakat, bangsa, dan negara. tujuan Pendidikan Nasional adalah untuk mengembangkan potensi peserta didik agar menjadi manusia beriman dan bertaqwa kepada Tuhan Yang Maha Esa, berahlak mulia, berilmu, kreatif, mandiri dan menjadi warga negara yang demokratis serta bertanggung jawab. Jadi tujuan pendidikan adalah untuk meningkatkan kemampuan siswa dalam mengoptimalkan potensi kognitif, afektif, fisikomotorik dan mendorong siswa mengembangkan sikap bertanggung jawab terhadap kehidupan pribadi dan sosialnya.

Teknik Pembelajaran Daring dipakai hampir semua sekolah pada masa pandemic covid-19 ini. Karena dapat menjangkau keberadaan siswa di manapun. Dan pembelajaran puisi yang dijadikan obyek penelitian ini sangat banyak memanfaatkan media untuk mendukung ketercapaian pembelajaran.(Bilfakih \& Qomarudin,2015). Teknik Pembelajaran Daring dianggap sebagai pembelajaran yang menyenangkan dan mudah penggunaannya. Pembelajaran bahasa Indonesia di sekolah menekankan pada pemerolehan empat keterampilan. Keempat keterampilan terdiri atas keterampilan menyimak, berbicara, membaca, dan menulis. Keempat keterampilan berbahasa disajikan secara terpadu, Namun, guru dapat memberikan tekanan pada satu atau dua keterampilan tersebut secara berbarengan. Seperti pada materi menulis cerita inspiratif guru lebih kearah satu keterampilan, yaitu keterampilan menulis. Keterampilan menulis merupakan keterampilan yang bersifat produktif, artinya keterampilan yang menghasilkan tulisan.

Materi membuat cerpen sangat cocok diberikan pada pandemic ini karena proses kreatif membuat cerpen dapat dilakukan dirumah, individu dan mandiri.Dan aplikasi yang digunakan adalah GCR. Jadi melihat bagaimana proses pembelajaran membuat cerpen dengan dengan menggunakan aplikasi GCR. Seorang penulis haruslah menyadari benar-benar bahwa menulis itu adalah suatu alat informasi atau pikiran, perasaan yang efektif dan tepat guna. Dari suatu komunikasi itulah kita bisa temui, apa isi dari tulisan tersebut dan bisa dimengerti oleh semua orang atau si pembacanya.Menulis merupakan kegiatan yang produktif dan ekspektif. Menulis merupakan sebuah proses kreatif menuangkan gagasan dalam bentuk bahasa tulis dalam tujuan, misalnya memberi tahu, meyakinkan, atau menghibur. Keterampilan menulis ini tidak bisa datang begitu saja, secara tiba-tiba orang bisa menulis. Tetapi harus melalui banyak latihan dan praktik. Keterampilan menulis dewasa ini sangat dibutuhkan untuk 
menunjukan kita termasuk manusia terpelajar. Sementara Akhadiah (1989: 56) menyatakan bahwa menulis merupakan mengorganisasikan gagasan secara sistematis serta mengungkapkannya secara tersurat.

keterampilan menulis adalah suatu kegiatan yang produktif dan ekspresif dalam berpendapat dan menuangkan gagasan serta dapat membuat sebuah cerita dalam bahasa tulis, keterampilan menulis juga dapat berfungsi untuk berkomunikasi secara tidak langsung dan tidak secara tatap muka dengan pihak lain. Fiksi adalah sebuah karya yang imajinatif atau sebuah cerita yang menawarkan permasalahan dalam kehidupan. Fiksi menawarkan berbagai permasalahan manusia dan kemanusiaan, hidup dan kehidupan. Fiksi menceritakan berbagai masalah kehidupan manusia dalam interaksinya dengan lingkungan dan sesama, interaksinya dengan diri sendiri, serta interaksinya dengan Tuhan.Pengarang menghayati berbagai permasalahan tersebut dengan penuh kesungguhan, yang kemudian diungkapkannya kembali melalui sarana fiksi sesuai dengan pandangannya. Baik dengan sumber tema imajinatif atau dari tema kehidupan nyata. Atau gabungan dari keduanya Sedangkan cerpen termasuk kedalam teks fiksi, Cerpen sendiri adalah sebuah cerita yang hanya mempunyai satu pusat tema, sehingga cerpen tidak memerlukan banyak waktu ketika kita membacanya. .

Teknik pembelajaran daring adalah pembelajaran jarak jauh sebuah informasi dengan menggunakan teknologi internet seperti Google Froom, Whatsapp dll. Dalam proses pembelajaran. Menurut Drouin, (2013) dalam Jurnal Oktavian (2020: 55). "Pembelajaran daring adalah menciptakan lingkungan belajar menjadi salah satu aspek penting untuk mewujudkan lingkungan belajar peserta didik dalam memudahkan memproses kegiatan pembelajaran secara online. Berdasarkan pendapat tersebut dapat disimpulkan bahwa pembelajaran daring yaitu proses untuk menciptakan pembelajaran yang menyenangkan bagi peserta didik dalam proses pembeljaran. Penggunaan pembelajaran daring akan sangat efektif untuk peserta didik dalam pembelajaran.

Menurut Bilfaqih, (2012:37) "pembelajaran daring adalah pembelajaran yang diselenggarakan melalui jaringan internet. Berdasarkan pendapat tersebut dapat disimpulkan bahwa pembelajaran daring yaitu berbasis internet pembelajaran secara jarak jauh (online) agar pengetahuan peserta didik lebih luas dalam proses pembelajaran. Menurut Efendi (2020:45) "Pembelajaran Daring merupakan pembelajaran yang berlangsung dipelajaran dimana pengajar dan yang diajarkan tidak 
bertatap muka secara langsung dan memanfaatkan jaringan internet dalam proses pembelajaran. Berdasarkan pendapat tersebut dapat disimpulkan bahwa pembelajaran daring adalah proses pembelajaran secara online dimana siswa belajar secara jarak jauh seperti menggunakan Google Form dan lain-lain agar siswa tidak jenuh dalam proses pembelajaran.

Media daring demikian popular di era pandemi covid-19 ini. Semua orang menggunakan ini sebagai sarana komunikasi hampir disegala lini kehidupan,termasuk dalam pembelajaran di sekolah. Menurut Efendi (2020:76) dengan menggunakan media Pembelajaran Daring guru tidak dibatasi oleh aturan dalam memilih dan menggunakan media pembelajaran online yang akan digunakan. Namun guru harus mengacu pada prinsip pembelajaran daring sehingga komunikasi dalam pembelajaran dapat dilakukan dengan baik. Namun guru harus tetap mengacu pada prinsip pembelajaran daring. Guru dan siswa harus bisa menggunakan media ini dengan baik sehingga tujuan dari pembelajaran itu bisa tercapai. .Ciri dari Pembelajaran Daring adalah integrasi teknologi dan inovasi yang ada di dalamnya. Media online yang biasa digunakan dalam pembelajaran online di SMPN 7 seperti Google Form, Wa, Zoom, Google Net,dan Google Class Room.

\section{B. METODELOGI PENELITIAN}

Penelitian ini menggunakan pendekatan kualitatif dengan jenis metode penelitian deskriptif kualitatif. Menurut Sugiyono (2016:7) bahwa metode penelitian kualitatif adalah metode penelitian yang berlandaskan pada Filsafat postpositivme, digunakan untuk meneliti kondisi objek yang ilmiah, dan peneliti sebagai instrument, dengan teknik pengumpulan data dilakukan secara trigulasi, analisis data bersifat induktif atau kualitatif dan hasil penelitian kualitatif ini lebih menekankan makna dari pada generalisasi Menurut Sugiono (2017:216) Pada penelitian kualitatif, peneliti memasuki situasi sosial tertentu, melakukan wawancara kepada orang-orang yang dipandang tahu tentang situasi tersebut.Teknik pengumpulan data merupakan langkah yang paling utama dalam penelitian. Data merupakan sumber untuk pemecahan masalah penelitian. Teknik pengumpulan data yang dilakukan oleh peneliti ini adalah 1) Google Form merupakan salah satu aplikasi virtual yang menurut penulis lebih sederhana, mudah dipahami dan digunakan. Penggunaan Google Form dengan menggunakan akun email google masing-masing. 2) Wawancara, menurut Sugiyono (2016:194) bahwa 
wawancara sebagai teknik pengumpulan data apabila peneliti ingin melakukan study pendahuluan untuk menemukan permasalahan yang harus diteliti, apabila penelti ingin mengetahui hal-hal dari responden yang lebih mendalam teknik tersebut untuk mengetahui informasi teknik pembelajaran daring di SMPN 7 Kota Tangerang. 3) Kuesioner (Angket), menurut Arikunto (2014:194) kuesioner merupakan teknik pengumpulan data yang dilakukan dengan cara memberi seperangkat pertanyaan atau pernyataan tertulis kepada responden untuk dijawabnya. Kuesioner merupakan teknik pengumpulan data yang efisien bila peneliti tahu dengan pasti variabel yang akan diukur dan tahu apa yang bisa diharapkan dari responden. Selain itu, kuesioner juga cocok digunakan bila jumlah responden cukup besar dan tersebar di wilayah yang luas. Peneliti menggunakan angket untuk diisi oleh siswa kelas 9.

\section{HASIL PENELITIAN DAN PEMBAHASAN}

\section{Pembelajaran Daring}

Tahap wawancara yang penulis lakukan pada guru mapel bhs Indonesia kelas 9 dengan cara melakukan wawancara langsung mengenai kegiatan beajar mengajar pada saat masa pandemi ini dalam proses pembelajaran daring. wawancara ini dilakukan dengan mencari informasi mengenai aktivitas siswa dan guru pada saat pembelajaran daring. Kegiatan wawancara ini dilakukan dalam rentang waktu 1 hari. Berdasarkan hasil wawancara, penulis dapat menyimpulkan bahwa pembelajaran daring dipilih dikarenakan metode mengajar yang dipakai oleh guru mudah hal ini dapat dibuktikan oleh antusias siswa belajar.

Setelah siswa selesai pembelajaran daring ke siswa lalu guru meminta AA untuk mengungkapkan kembali materi tersebut AA mengungkapkannya dengan tepat., AA menjawab tentang satu angket yang dibuat misalnya apakah kalian senang dengan pembelajaran jarak jauh (daring) yang baru kalian ikuti? Dan siswa menjawab sangat setujuh dan seterusnya. hal ini dapat diketahui ketika pengisian angket, dengan seberapa seneng siswa belajar dengan pembelajaran dring ketika peneliti menyebar sebuah link pertanyaan yang siswa alami dengan belajar secara daring, dalam menyebar sebuah link siswa antusias menjawab angket yang di berikan oleh penulis beberapa siswa menjawab sangat suka belajar bhs Indonesia melalui daring, ada siswa yang menjawab suka belajar bhs Indonesia dan ada pula menjawab tidak suka pembelajaran bhs Indonesia melalui daring. Sebelum mengisi angket siswa terlebih dahulu berdoa 
sesuai dengan keyakinan masing - masing, setelah itu siswa memulai menjawab apakah sangat suka, setuju, tidak suka dengan pembelajaran daring pada bhs Indonesia, setelah siswa mengisi penulis menganalisi berapa siswa yang menjawab sangat suka, suka, tidak suka dengan berapa persen terhadap beberapa siswa yang menjawab pertanyaan yang dikirim link melalui google form.

Berdasarkan hasil wawancara langsung penulis bersama wali kelas dengan mengajukan 20 pertanyaan mengatakan bahwa pembelajaran daring dikatakan efektif atau tidak, jika penulis melihat kondisi masa pandemi seperti ini memang semua orang terutama guru dan siswa melakukan proses kegiatan mengajar dalam proses pembelajaran daring. Oleh karena itu guru dan siswa wajib mengikuti perintah dari dinas pendidikan bahwa tidak memungkinkan untuk pembelajaran tatap muka oleh karena itu guru dan siswa wajib mengikuti arahan dari dinas pendidikan. Oleh karenanya proses pembelajaran saat pandemik saat ini menggunakan pembelajaran daring baik dari guru maupun siswa.

Dalam proses pembelajaran daring memang tidak menggunakan tatap muka sehingga guru dalam proses pembelajaran tidak melihat aktifitas siswa secara langsung dikarenakan dalam masa pandemik saat ini, jadi guru dan siswa hanya melakukan proses pembelajaran secara daring salah satunya menggunakan google form dengan cara guru membuat pertanyaan kepada pesrta didik melalui google form dan siswa langsung menjawab pertanyaan. Pertanyan yang dibuat penulis disebar oleh siswa melalui link dengan google form. Penulis ambil satu siswa AA dengan pertanyaan. Dengan adanya pembelajaran melalui daring siswa dapat memahami pembelajaran melalui google form. Siswa AA menjawab sangat suka, teman lainnya juga menjawab pertanyaan-pertanyaan yang diberikan penulis.Dapat disimpulkan bahwa pembelajaran daring pada bhs Indoneesia dipilih dikarenakan metode mengajar yang dipakai oleh guru mudah diterima oleh siswa.Kesimpulan yang dapat diambil dari hasil wawanacara mengenai pembelajaran daring minatnya cukup baik walaupun memang belum seluruh siswa yang tertarik.

Pada tahap angket dapat dilihat dari data yang telah dikumpulkan kemudian dianalisis dengan tujuan dapat menarik kesimpulan dengan baik. Pengolahan data yang telah tersedia dilakukan dengan cara menganalisis dan menafsirkan setiap data dari 
masing-masing responden. Setelah diperoleh data dari hasil angket, kemudian data diolah dalam bentuk tabel deskripsi persentase dengan menggunakan rumus :

$\mathrm{P}=\frac{f}{N} \times 100 \%$

Keterangan :

$F=$ Frekuensi yang sedang dicari persentasenya

$N=$ Number of Cases (jumlah frekuensi/banyaknya individu)

$\mathrm{P}=$ Angka presentase

Adapun pembahasan mengenai pertanyaan yang telah diberikan kepada responden dapat dilihat dalam tabel-tabel persentase berikut :

Tabel 4. 1 Suka Terhadap Pembelajaran Cerpen

\begin{tabular}{|c|c|c|}
\hline Alternatif Jawaban & Frekuensi & Persentase \\
\hline Sangat Suka & 8 & $35 \%$ \\
\hline Suka & 13 & $56 \%$ \\
\hline Biasa saja & 2 & $9 \%$ \\
\hline Tidak Suka & 0 & 0 \\
\hline Sangat Tidak Suka & 0 & $100 \%$ \\
\hline Jumlah & 23 & \\
\hline
\end{tabular}

Berdasarkan tabel tersebut dapat diketahui bahwa 35\% siswa sangat menyukai pelajaran IPS, 56\% siswa menyukai pelajaran daring, 9\% merasa biasa saja . hal tersebut dapat disimpulkan bahwa sebagian besar siswa menyukai dan hanya sebagian kecil siswa yang merasa biasa saja dengan pelajaran daring.

Tabel 4. 2 Rasa Suka Terhadap Pembelajaran Daring Melalui Google Form

\begin{tabular}{|c|c|c|}
\hline Alternatif Jawaban & Frekuensi & Persentase \\
\hline Sangat Suka & 12 & $52 \%$ \\
\hline Suka & 11 & $48 \%$ \\
\hline Biasa saja & 0 & $0 \%$ \\
\hline Tidak Suka & 0 & $0 \%$ \\
\hline Sangat Tidak Suka & 0 & $100 \%$ \\
\hline Jumlah & 23 & \\
\hline
\end{tabular}


Berdasarkan tabel tersebut dapat diketahui bahwa 52\% siswa sangat menyukai pembelajaran daring, $48 \%$ siswa menyukai . Dengan demikian dapat disimpulkan bahwa sebagian besar siswa sangat menyukai pembelajaran daring, hal tersebut menunjukkan bahwa metode mengajar yang digunakan oleh pembelajaran daring dapat diterima oleh sebagian besar siswa. Hal ini disimpulkan pembelajaran daring itu efektif menggunakan google form disaat pandemik seperti ini.

Berdasarkan hasil wawancara yang dilakukan maka secara garis besar dapat ditarik kesimpulan bahwa pembelajaran daring menggunakan google form dapat dikatagorikan cukup tinggi. Hal tersebut dapat dilihat dari hasil angket tabel 4.1, 4.2, menunjukan hasil positif terhadap pembelajaran daring. Hasil tabel 4.1 dengan butir pertanyaan : siswa suka terhadap pemb Cerpen. Adapun rincian hasil persentase table 4.1 yaitu ada 8 siswa dinyatakan sangat suka pembelajaran Bhs. Indonesia yaitu 35\%. Siswa sangat menyukai karena cerpen selain dapat menghibur juga terdapat nilai-nilai kemanusiaan. Sementara Ada 13 siswa dinyatakan suka yaitu 56\%.dikarenakan ilmu yang mempelajari kegiatan atau peristiwa yang terjadi pada kebiasaan sehari-hari, sehingga pelajaran ini meningkatkan apa yang terjadi pada dirinya masing-masing Sehingga siswa tidak dibebankan dengan ilmu pasti atau hitungan yang membuat mereka pusing akan menghafal rumus dalam pembelajaran. Ada 2 siswa dinyatakan biasa saja yaitu 9\%. Siswa merasa biasa saja karena didalam pemlajaran ini siswa di didik untuk hafalan dan pelajaran ini tidak menggunakan hitungan dan hal ini siswa bisa belajar melalui dikehidupan sehari-hari sehingga mereka bisa mempelajarinya dengan cara melihat apa yang telah terjadi dilingkungan masyarakat dalam hal ini dimedia sosial (sosmed) siswa sekarang sangat mengerti dalam berinteraksi sosial didalam lingkungan masyarakat, selain itu siswa menganggap sumber materi yang dijumpai banyak di dapat dari goole, buku panduan.Sementara pada siswa tidak suka didapati tidak satu siswa pun yaitu $0 \%$. Dikatagorikan dari hasil persentase yang paling banyak dipilih oleh siswa yaitu pilihan suka karena persentase tertinggi yaitu 56\% dan dapat dilihat dari jawaban Aisyah mengapa ia memilih suka, ia mengatakan karena cerpen dapat memberi hiburan.

Hasil tabel 4.2 dengan butir pertanyaan rasa suka terhadap pembelajaran daring yaitu ada 12 siswa dinyatakan sangat suka pembelajaran daring, ini adalah terbesar $52 \%$. Siswa sangat menyukai pembelajaran daring melalui google form karena pembelajaran daring dianggap pembelajaran yang sangat menyenangkan, dengan 
pembelajaran daring siswa lebih santai dalam mengerjakan tugas-tugasnya. Selain itu siswa juga bisa mengerjakan tugas-tugasnya seiring dengan sifat-sifat anak yang suka bermain, menonton TV dan sarapan/makan siang. Selain itu pembelajaran dari dianggap pembelajaran yang mudah, dimana siswa hanya menerima link yang diberikan oleh guru melalui whatsaap grup (WAG) Setelah diterima lalu link tersebut di klik sehingga muncul pertanyaan-pertanyaan. Sebelum menjawab siswa diwajibkan meulis nama dan kelas pada kolam yang sudah disediakan, setelah itu baru siswa menjawab soal-soal yang suda diberikan melalui google form. Sementara Ada 11 siswa dinyatakan menyukai pembelajaran dari yaitu $48 \%$. siswa suka pembelajaran daring melalui google form karena pembelajaran daring tersebut dianggap pembelajaran yang tidak menjenuhkan dan juga siswa tidak merasa takut atau tertekan terhadap materi yang diberikan oleh guru dan juga siswa merasa terbantu dalam hal belajar dirumah karena didampingi oleh orang tua dirumah.

Pembelajaran daring memungkinkan siswa untuk belajar dimana saja sehingga tidak perlu bolak balik dari satu tempat ke tempat lain sehingga dapat menghemat waktu dan waktu belajarnya pun tidak kaku sehingga bisa disesuaikan dengan kegiatan sehari-hati siswa. Sementara pada siswa biasa saja, tidak suka dan sangat tidak suka dengan pembelajaran daring tidak didapati satu siswa pun yaitu $0 \%$, karena siswa meminati tehnik pembelajaran daring sebagai metode pembelajarannya. Dikatagorikan dari hasil persentase yang paling banyak dipilih oleh siswa yaitu pilihan sangat suka karena persentase tertinggi yaitu 52\% siswa yang dinyatakan sangat suka ,dapat dilihat dari jawaban ahmad mengapa dia memilih sangat suka, dia mengatakan, karna dia menyukai pembelajaran daring, ahmad menyukai pembelajaran daring karena banyak menambah pengetahuan dan wawasan tentang informasi belajar secara online dengan teknologi yang sudah canggih seperti leptop, hp dll.

Faktor pendukung tingginya pembelajaran daring karena untuk menambah pengetahuan teknologi, wawasan dan informasi yang diberikan oleh guru dalam kegiatan pembelajarannya. Hal ini dibuktikan dengan adanya pembelajaran daring yang diterapkan oleh guru ketika siswa sedang belajar. Sebagian besar siswa juga menyukai hal baru seperti daring, hal ini dapat dilihat ketika siswa diberikan waktu untuk mengerjakan tugas menggunakan daring seperti google form siswa mengerjakannya dengan tepat waktu. dan juga sarana dan prasarana seperti komputer, leptop yang ada 
disekolahan tersebut. Selalu memotivasi siswa agar tergugah dalam dirinya sendiri bahwa pembelajaran daring itu sangat penting. faktor penghambat yang menghambat dalam pembelajaran daring. Faktor penghambat tersebut antara lain adalah dari diri anak itu sendiri yang tidak adanya kemauan untuk berusaha mencari tahu dalam menggunakan teknologi, seperti leptop dan komputer. Tidak adanya motivasi yang diberikan guru kepada siswanya dan faktor sarana prasana yang belum sempurna seperti kurangnya leptop dan komputer yang ada di sekolah tersebut fasilitasnya terbatas di sekolahan tersebut.

\section{SIMPULAN DAN SARAN}

Peserta didik merasa pembelajaran daring lebih menyenangkan, karena dirasa lebih santai dan efisien. Guru mapel Sudah menguasai teknik pembelajaran daring dengan cukup baik hal ini dapat dilihat dari hasil wawancara yang dilakukan peneliti bahwa guru sudah memberikan metode daring menggunakan Google Form Hal ini dibiasakan oleh guru agar siswa terbiasa dalam pembelajaran daring, guru juga tidak lupa ketika dalam kegiatan pembelajaran maupun diakhir pembelajaran, guru selalu memberikan motivasi kepada siswanya. Guru harus selalu menjadi motivator bagi siswanya.

\section{E. DAFTAR PUSTAKA}

Arikunto. (2014). Prosedur Penelitian. Bandung: PT Rineka Cipta.

Bilfaqih \& Qomarudin. (2015). Esensi Penyusunan Materi Pembelajaran Daring. Deepublish : Yogyakarta.

Bilfaqih, Y. \&. (2012). Esensi Pengembangan Pembelajaran Daring. Yogyakarta: CV Budi Utama.

Efendi, dkk. (2020). Efektifitas Implementasi Video Pembelajaran Daring Doa Seharihari Selama Pandemi Covid-19. Seminar Nasional Pengabdian Masyarakat LPPM UMJ.

Oktavian \& Aldya. (2020). Efektifitas Pembelajaran Daring Terintegrasi di Era Pendidikan 4.0. Didaktis : Jurnal Pendidikan dan Ilmu Pengetahuan. 20(2).

Sugiarto, E. (2014). Mahir Menulis Cerpen. Yogyakarta: Suaka Media.

Sugiyono. (2016). Metode Penelitian Kuantitatif, Kualitatif dan R\&D. Bandung: Alfabeta.

Sugiyono. (2017). Metodologi Kuantitatif, Kualitatif, dan R\&D. Bandung: Alfabeta. 